\title{
Az Gören Öğrencilerin Okuma Hatalarının Hata Analizi ile Incelenmesi*
}

\author{
Examining of Reading Errors of Students with Low Vision by \\ Miscue Analysis
}

\author{
Fatih Emrah DEMIR**, E. Rüya ÖZMEN***
}

\begin{abstract}
Öz: Okuma hataları, okuyucunun dilin ipucu sistemleri ile metni anlamada kullandığı okuma stratejileri hakkında kapsamlı bilgiler sunar. $\mathrm{Bu}$ araştırmada az gören ve gören öğrencilerin okuma hatalarının hata analizi ile incelenmesi ve anlama sorularına verilen cevaplara yansımasının belirlenmesi amaçlanmıştır. Araştırmaya görme engelliler ilk ve ortaokullarına devam eden 9 az gören öğrenci ile gören öğrencilerin devam ettiği ilk ve ortaokullarda okuyan 9 gören öğrenci katılmıştır. Öğrencilerin okuma hatalarını değerlendirmek için hata analizi yapılmıştır. Hata analizi çerçevesinde, dilin ipucu sistemlerini oluşturan sözdizimi, anlam, kullanım ve harf-ses ilişkisi incelenmiştir. Araştırmanın sonuçları, az gören öğrencilerin sözdizimi, anlam, kullanım ve harf-ses ilişkisi alanlarında gören öğrencilerden farklılık gösterdiği belirlenmiştir. Araştırma sonuçları tartışılmış ve ileri uygulamalar ile araştırmalara yönelik önerilerde bulunulmuştur.
\end{abstract}

Anahtar Kelimeler: Az gören öğrenciler, okuma hataları, hata analizi

\begin{abstract}
Reading errors provide comprehensive information about the reading strategies that the reader uses to understand the text and language clue systems. The aim of this study is to examine the reading errors by using error analysis and determine reflection of reading comprehension in students with low vision and sighted. The study was attended by 9 sighted students attending primary and secondary schools with 9 low vision students attending primary and secondary schools for the visually impaired. Miscue analysis was conducted to evaluate students' reading errors. In the context of error analysis, the syntax, meaning, usage and letter-sound relationship of language hint systems were examined. The results of the study show that students with low vision differentiate from students who are sighted in terms of syntax, meaning, usage and letter-sound relationship. The results of the study were discussed and recommendations were made for advanced applications and research.
\end{abstract}

Keywords: Students with low vision, reading errors, miscue analysis

\section{Giriş}

Okuma becerisi, bireylerin bağımsız olarak yaşamalarında, eğitim-öğretimlerini sürdürmelerinde gerekli olan temel akademik becerilerdendir. Okuma becerisi, yetişkinlik evresinde yaşama uyum becerileri gibi bireyin yaşamını olumlu yönde etkilemekte ve kolaylaştırmaktadır (Karasu, 2011). Okuma becerisi, aynı zamanda okul döneminde gerçekleştirilen öğrenme yaşantılarına birincil, temel kaynak oluşturması açısından önemli bir beceridir (Güzel, 1998; Güzel-Özmen, 2013).

Okuma; görme, dikkat, algılama, hatırlama, seslendirme, anlamlandırma, sentezleme, çözümleme ve yorumlama gibi farklı bileşenlerden oluşan, karmaşık bir zihinsel süreçtir. Alan yazındaki okuma tanımları analiz edildiğine, okumanın farklı unsurları üzerine vurgu yapıldığ görülmektedir. Araştırmacılar okumayı, çözümlenen bilgi birimleri arasında ilişki kurma ve yazılı sembollerin çözümlenmesi ile çözümlenen sembollerin anlamlandırılması süreci (Güzel, 1998); okuyucunun var olan ön bilgilerini kullandığı, yazar ve okuyucu arasında dinamik bir

\footnotetext{
* Bu makale 1. yazarın, 2. yazarın danışmanlığında hazırladığı doktora tezinden türetilmiştir.

** Arş. Gör. Dr., Gaziantep Üniversitesi, Gaziantep Eğitim Fakültesi, Gaziantep-Tükiye, ORCID: 0000-0003-4964087X, e-posta: fatihemrah.gef@gmail.com

*** Prof. Dr., Gazi Üniversitesi, Gazi Eğitim Fakültesi, Ankara-Türkiye, ORCID: 0000-0000-1234-5678, e-posta: ruyaozmen@hotmail.com
} 
etkileşime dayalı uygun bir yöntem ve amaç doğrultusunda gerçekleştirilen anlam oluşturma süreci (Akyol, 2007); görme, algılama, seslendirme, anlama, zihinsel ve bilişsel yapılandırma gibi beynin farklı yetilerinin birlikte kullanıldığı karmaşık bir süreç (Öz, 2006) olarak betimlemişlerdir.

Okuma becerisinin içerdiği bileşenler incelendiğinde, çok katmanlı ve aşamalı bir beceri olduğu karşımıza çıkmaktadır. Armbruster, Lehr ve Osborn (2001) okuma becerisinin, ses bilgisel farkındalık, okuma akıcılığı, kelime bilgisi ve okuduğunu anlama unsurlarından oluştuğunu vurgulayarak; gerçekleştirilecek sistematik okuma müdahalelerinin okumanın bu unsurlarını temel alması gerektiğini belirtmiştir. Okumanın unsurları üzerine yapılacak sistematik müdahalelerin nihai amacı, öğrencinin okuduğu metinden anlam çıkarabileceği düzeye gelebilmesidir (Epçaçan, 2009).

Bireyin var olan görmesinin etkin bir şekilde kullanmasının, okuma ve yazma gibi görmeyle ilgili davranışlarını olumlu yönde etkileyeceğini ve var olan görme becerisini kullanımının geliştirilebileceğini vurgulayan davranışsal optometri, görme becerisini kullanmayla ilgili gerçekleştirilecek müdahalelere de öncülük etmektedir (Harris, 2007). Bu alanda çalışan araştırmacılardan Maples (2003) Amerika Birleşik Devletleri'nde ilköğretim öğrencileri ile gerçekleştirdiği betimsel araştırmasında, etnik kökenin, sosyoekonomik düzeyin ve görme duyusundaki sınırlılıkların akademik başarı üzerindeki değişken etkilerini incelemiştir. Araştırmacı, etnik köken ve sosyoekonomik düzeyin akademik başarı üzerindeki etkisi anlamlı düzeyde olsa da; akademik başarı üzerindeki en büyük etkinin görme duyusundaki sınırlılıklardan kaynaklandığını bulmuştur. Araştırma, görme duyusuna ilişkin risk faktörlerini ortaya koyması, medikal ve eğitsel müdahalelerin gerekliliği ve önemini vurgulaması açısından değerlidir. Davranışsal optometri alanında yapılan araştırmalarda, görme duyusundaki sınırlılıkların akademik beceriler, özellikle de okuma becerisi üzerindeki etkisi henüz net olmamakla birlikte ortaya koyulmaktadır (Maples, 2003).

Az gören öğrencilerin akademik bilgiyi edinmelerindeki başat kaynaklardan birisi olan okuma becerisi, az gören bireylerin bağımsız bir şekilde yaşamaları ve yetişkinlik dönemlerinde meslek yaşantılarını sürdürmeleri için de kazanmaları gereken en kritik becerilerden birisi olarak öne çıkmaktadır. Serino (2007) görme engelli öğrencilerin eğitiminde gören akanlarınınkinde olduğu gibi okuma becerisinin öğrenme için temel bir beceri olarak ele alınması gerektiğini belirtmiş̧tir. Araştırmac1, görme engelliler öğretmenlerinin birincil sorumluluklarının arasında görme engelli öğrencilerine okuma becerilerinin öğretimi olduğunu bildirmiştir. Az gören öğrencilerin, görme engelli şemsiye terimi altında yer aldığı dikkate alındığında, okuma becerisinin önemi, az gören öğrenciler için de açıkça vurgulanabilir.

$\mathrm{Az}$ gören öğrenciler, eğitsel gereksinimleri açısından total görme engellilerden (hiç görmeyen öğrenciler) bir dizi farklılık göstermektedir. Az gören öğrencilerin eğitsel gereksinimlerini en üst düzeyde karşılanabilmesi için gözlük, büyüteç gibi materyallerin kullanılması ve büyük puntolu yazı, uygun 1şıklandırma, renk kontrastı gibi materyal ve çevre uyarlamalarının yapılması gerekmektedir (Tuncer, 2003). Gerçekleştirilen bazı araştırmalarda az gören öğrencilerin gören akranlarına göre daha düşük okuma performansına sahip olduğuna yönelik kanıtlar sunulmaktadır (Corley ve Pring, 1993a, 1993b; Fellenius, 1999). Alan yazında az gören öğrencilerin okuma becerilerinin sınırlılığını ortaya koyan bulgular ağırlıklı olmakla beraber, bazı araştırmalarda az gören öğrencilerin akranlarıyla aynı hatta daha iyi düzeyde okuma performansları sergilediklerine dair veriler de bulunmaktadır (van Bon, Adriaanses, Gompel ve Kouwenberg, 2000).

Az gören öğrencilerin okuma performansları ile ilgili çalışmalarda az gören öğrencilerin okuma hatalarının gören akranlarından daha yüksek olduğu bulunmuştur (Douglas, Grimley, Hill, Long ve Tobin, 2002; Douglas, Grimley, McLinden ve Watson, 2004). Labov ve Baker (2010) okuma hatalarını metindeki sözcükleri olduğundan farklı ve yanlış bir şekilde, metin yazarının vermeyi amaçladığı anlama uygun olmayan bir sesletimle okumak şeklinde betimlemiştir. Okuma hatalarının öğretmenlere, öğrencilerinin okuduğunu anlama becerilerine ve çözümlemedeki problemlerine yönelik bilgilendirici rolü bulunmaktadır (Goodman, 1969: McKenna ve Picard, 2006). Bu nedenle okuma hataları, öğretmenlerin uygun müdahaleleri 
düzenlemesi açısından önemli bir kaynak sunmaktadır. Okuma hataları ile okuyucuların düşünce ve dilin ipucu sistemlerini (anlam bilim, söz dizimi, kullanımbilim ve harf-ses ilişkisi) kullanmalarına (Davenport, 2002) ve anlama süreçlerine yönelik kapsamlı bilgiler edinilebilmektedir. Karasu (2011), gerçekleştirdiği alan yazın taraması ile okuma hatalarının öğrencilerin kullandıkları okuma stratejilerinin göstergeleri ve okuma becerileri hakkında bilgi veren ipuçları olduğunu ve bu hataların tek başına hata olarak değerlendirilmemesi gerektiğini belirtmiş̧tir. Bu bağlamda az görenlerin okuma hatalarının nispeten daha fazla olduğu yönündeki bulguların Türk dili çerçevesinde incelenmesi ve bu konuda az gören öğrencilerin okuma hatalarına hata analizi çerçevesinde yaklaşılması, oluşturulacak eğitsel müdahalelere bilimsel temel oluşturması açısından değerlidir. Bu araştırmada az gören ve gören öğrencilerin okuma hatalarının hata analizi ile incelenmesi ve anlama sorularına verilen cevaplara yansımasının belirlenmesi hedeflenmiştir.

\section{Yöntem}

\section{Araştırma modeli}

Bu çalışmada, az gören öğrenciler ile gören öğrencilerin öykü türü metinlerde okuma hatalarının incelenmesi amacıyla nitel araştırma modeli kullanılmıştır. Yıldırım (1999) nitel araştırmaların, belirli bir problemin sistematik ve mantıklı bir şekilde yanıtlanmasını temel alan bir model olduğunu belirtmiştir. $\mathrm{Bu}$ araştırmada, nitel araştırma yöntemlerinden tanımlayıcı araştırma modelinden faydalanılmıştır (Yıldırım, 1999).

\section{Çalışma grubu}

Bu araştırmanının örnekleminin belirlenmesinde amaçlı örneklem yöntemlerinden ölçüt (kriter) örneklem yöntemi kullanılmıştır. Ölçüt (kriter) örneklem yöntemi, belirli ölçütleri sağlayan durumları belirleyerek araştırma sürecine katmayı temel alır (Baltacı, 2018). Bu araştırmada da katılımcıların belirlenme sürecinde bazı önkoşullar bulunmaktadır.

Araştırmaya görme engelliler ilk ve ortaokullarına devam eden 3, 4 ve 5. sinıf düzeyinin her birinden üç olmak üzere dokuz az gören öğrenci ile gören öğrencilerin devam ettiği ilk ve ortaokullarda okuyan 3, 4 ve 5. sinıf düzeyinin her birinden üçer olmak üzere dokuz gören öğrenci katılmıştır.

Az gören öğrencilerin seçim sürecinde bazı önkoşullar belirlenmiştir. Bu ön koşullar: a) okuma yazma sürecinde gören yazı (basılı Türk alfabesi) kullanmaları, b) az görme dışında bir ek yetersizliklerinin bulunmaması ve c) çözümleme becerisine sahip olmalarıdır. Gören çocuklar için de bazı önkoşullar belirlenmiştir. Bu ön koşular: a) herhangi bir yetersizliğe sahip olmamaları ve b) çözümleme becerisine sahip olmalarıdır.

Yukarıdaki ön koşullara sahip olan az gören öğrenciler dört farklı görme engelliler ilk ve ortaokulundan; gören öğrenciler ise beş farklı ilk ve ortaokuldan seçilmiştir. Seçilen öğrencilerle uygulama yapabilmek amacıyla öğrencilerin devam ettikleri okullardan ve aileden izin alınmıştır.

Çalışmaya az gören altı erkek üç kız öğrenci katılmıştır. Az gören öğrencilerden 3. sınıfa devam edenlerin ikisi erkek biri kız; 4. sınıfa devam edenlerin üçü erkek ve 5. sınıfa devam edenlerin biri erkek ikisi kızdır. Az gören öğrencilerin üçü görme cihazı kullanmaktadır. Bu öğrencilerden biri optik gözlük, ikisi el büyüteci kullanmaktadır. Diğer öğrencilerin herhangi bir cihaz kullanmadığı bilgisi öğretmenlerden alınmıştır. Görme cihazı kullanan öğrencilere, cihazlarını değerlendirme sürecinde kullanmalarına izin verilmiştir.

Araştırmaya katılan az gören öğrenciler 16, 18, 20 ve 24 puntoluk yazıları okumaktadır. Az gören öğrencilerden yedisi yalnızca gören yazı ile okuma yazma çalışmalarını yürütmekte, iki öğrencinin ise birincil okuma aracı gören yazı ve ikincil okuma aracı kabartma yazıdır.

Gören öğrencilerin altısı kız üçü erkektir. Gören öğrencilerden 3. sınıfa devam edenlerin ikisi erkek biri kız; 4. sınıfa devam edenlerin biri erkek ikisi kız ve 5. sinıfa devam edenlerin ikisi kız biri erkektir. Gören öğrencilerin okuma materyallerinin hazırlanmasında bulundukları sınıf düzeyinde kullanılan Türkçe ders kitapları temel alınmıştır. 


\section{Veri toplama araçları}

\section{Katılımcılara yönelik bilgi formlar}

$\mathrm{Bu}$ araştırma kapsamında yer alan az gören ve gören öğrencilere yönelik bilgilerin edinilebilmesi amacıyla araştırmacılar tarafından iki bilgi formu geliştirilmiştir. $\mathrm{Bu}$ formlar öğretmenlerin doldurması için geliştirilen "Az Gören Öğrenci Bilgi Formu” ve "Gören Öğrenci Bilgi Formu"dur. $\mathrm{Bu}$ formlarda öğrencilerin demografik bilgilerinin yanı sıra okuma becerilerine yönelik sorular yer almaktadır. Ayrıca, Az Gören Öğrenci Bilgi Formu'nda, az gören öğrencilerin görme durumları (kullandığı herhangi bir görme aracının olup olmadığı, görme yetersizliğinin türü, görme yetersizliğinin okumaya etkisi) ile ilgili sorular da bulunmaktadır.

\section{Okuma hatalarının değerlendirilmesinde kullanılan veri toplama araçları}

$\mathrm{Bu}$ araştırmada Karasu (2011) tarafindan geliştirilen Formel Olmayan Okuma Envanteri'nde (FOOE) yer alan 3, 4 ve 5. sınıf düzeyleri için yazılmış öykülerin A formlarından, hata analizi formlarından ve soru cevap formlarından yararlanılmıştır. Karasu (2011), FOOE kapsamında geliştirdiği öykülere ve değerlendirme araçlarına ilişkin geçerlik güvenirlik çalışmalarını gerçekleştirmiştir.

Öyküler:FOOE kapsamında hazırlanan öyküler her sınıf düzeyinde, birbirinin eş değeri olarak nitelendirilebilen lakin farklı öyülerden oluşan A ve B formları şeklinde düzenlenmiştir. Bu araştırmada, FOOE'nin 3, 4 ve 5. sınıf düzeyi için hazırlanmış A formu öykülerinden faydalanılmıştır. FOOE kapsamında öyküler okunabilirlik düzeyleri dikkate alınarak hazırlanmıştır. Öykülerin okunabilirlik düzeylerini ortaya koymak için öykülerde bulunan cümlelerin, diğer bir deyişle T-birimlerin ortalama uzunluğu ile yan cümlecik endeksi hesaplanmıştır. Metinlerin zorluk düzeyini ortaya koymada faydalanılan bir diğer analiz, sözcük farklılık puanının analiz edilmesidir. Sözcük farklılık puanının hesaplanabilmesi için öyküde bulunan farkl1 sözcükler belirlenmiştir. FOOE'de yer alan öykülerde kurulum (yer, zaman, karakterler), problem, içsel tepki, plan, girişim, girişim sonucu ve sonuç kısımları yer almaktadır. Öykülerin içerik geçerliği belirlenmiş, bu öykü konularının a)öğrencilerin bilgi, yaş ve sınıf düzeylerine uygunluğu, b) öykü bölümlerinin tamlığı, c) öykü konularının ve düzeylerinin denkliği, d) öykülerde kullanılan cümle yapıları ve sözcük çeşitleri, e) öykülerin okunabilirlik düzeyleri, f) soru çeşitleri ve g) sorulara cevap verme formları ile ilgili iki uzmandan görüş alınmıştır (Karasu, 2011; Karasu, Girgin ve Uzuner, 2013). Tablo 1'de FOOE'de yer alan öyküler ile ilgili özelliklere yer verilmiştir.

Tablo 1.

FOOE'ndeki 3, 4 ve 5. sınıf düzeyindeki A formundaki öykülerin okunabilirlik düzeyleri (Karasu, 2011).

\begin{tabular}{|c|c|c|c|c|c|c|c|c|c|}
\hline Düzey & Form & $\begin{array}{l}\text { Öykünün } \\
\text { Başlığ1 }\end{array}$ & $\begin{array}{l}\text { Sözcük } \\
\text { Sayıs1 }\end{array}$ & $\begin{array}{l}\text { T- } \\
\text { Birim } \\
\text { Say1s1 }\end{array}$ & $\begin{array}{l}\text { T Birimlerin } \\
\text { Ortalama } \\
\text { uzunluğu }\end{array}$ & $\begin{array}{l}\text { Cümlecik } \\
\text { Sayısı }\end{array}$ & $\begin{array}{l}\text { Yan } \\
\text { Cümlecik } \\
\text { İndeksi }\end{array}$ & $\begin{array}{l}\text { Farkl1 } \\
\text { Sözcük } \\
\text { Sayıs1 }\end{array}$ & $\begin{array}{l}\text { Sözcük } \\
\text { Farklılık } \\
\text { Puanı }\end{array}$ \\
\hline $\begin{array}{l}3 . \\
\text { sinif }\end{array}$ & A & $\begin{array}{l}\text { Ömer ve } \\
\text { Güvercin }\end{array}$ & 174 & 26 & 6.69 & 53 & 2.03 & 118 & 6.32 \\
\hline $\begin{array}{l}4 . \\
\text { sinif }\end{array}$ & A & $\begin{array}{l}\text { İpek } \\
\text { Ormanda }\end{array}$ & 235 & 32 & 7.34 & 71 & 2.21 & 168 & 7.75 \\
\hline $\begin{array}{l}5 . \\
\text { sinif }\end{array}$ & A & Sel & 287 & 36 & 7.97 & 92 & 2.55 & 209 & 8.72 \\
\hline
\end{tabular}

Öğrencilerin okuma hataları ile anlama arasında bir ilişki olup olmadığını belirlemek için okutulan öykülere göre anlama soruları sorulmuştur. Tablo 2'de öykülerdeki soru sayı ve türlerine ilişkin bilgilere yer verilmiştir. 
Tablo 2.

Öykülerdeki Soru Sayı ve Türleri (Karasu, 2011)

\begin{tabular}{lcccc}
\hline & \multicolumn{3}{c}{ Soru türleri } & \\
\cline { 3 - 5 } Sinıf düzeyi & Metinsel açık & Metinsel kapalı & Bilgi-Deneyim & Toplam \\
\cline { 3 - 5 } 3. sinıf & 4 & 4 & 2 & 10 \\
4. sinıf & 4 & 4 & 2 & 10 \\
5. sinıf & 4 & 4 & 2 & 10 \\
\hline
\end{tabular}

Öykülerin yazı tipi ve satır aralığı az gören öğrencilere göre hazırlanmıştır. Çakmak, Karakoç, Şafak ve Kan'ın (2014) az görenler için ortaya koydukları şekilsel uyarlamalar incelenerek, öykülerin şekilsel özelliklerinde bu uyarlamalar temel alınarak uyarlamalar yapılmıştır. Çakmak ve diğerleri az gören öğrencilerin metinlerinin, Comic Sans ya da Century Gothic yazı tipinde, geniş karakter aralığı ve çift satır aralığı kullanılarak yazılmasını önermişlerdir. Bu bağlamda araştırmada kullanılan öyküler Comic Sans karakteri ile krem rengi kâğıt üzerine siyah baskı şeklinde tasarlanmıştır. Bunun nedeni hem parlamayı önlemek hem de uygun renk kontrastını sağlamaktır. Punto büyüklüklerine ve satır aralığına veri toplama sürecinde öğrencinin görme durumuna göre karar verilmiştir.

Gören öğrencilerin okuyacakları öykülerin düzenlenmesi amacı ile MEB ve diğer yayınevleri tarafından basılan 3, 4 ve 5. sınıf Türkçe ders kitapları incelenmiştir. Punto büyüklüğü, 3. Sınıf öğrencileri için 14, 4 ve 5. Sınıf öğrencileri için 12 olarak belirlenmiştir. Satır aralığ 1 1,5 olarak düzenlenmiştir. Yazı tipi olarak az gören öğrencilerin öykülerinin yazımında da yararlanılan Comic Sans seçilmiştir.

Hata Analizi (Miscue Analysis) Formlart: Bu araştırmada, öğrencinin öyküleri sesli okuma sürecinde sergilediği okuma hatalarına yönelik olarak cümlelerin dilin ipucu sistemleri; i) sözdizimi kabul edilebilirliği, ii) anlam kabul edilebilirliği, iii) yazarın iletmek istediği anlamın değişmesi ve iv) metinde yazan sözcükle öğrencinin yaptığı okuma hatası arasındaki harf-ses benzerliği incelenmiştir. Karasu'nun (2011) desenlediği hata analizi formu öğrencilerin hatalarını hata analizi yöntemi ile analiz etme amacı ile kullanılmıştır.

Soru Cevap Formları: Öğrencilerin,okuduğunu anlama sorularına verilen cevaplar soru cevap formu kullanılarak kayıt edilmiştir. Soru-cevap formu ilgili sınıf düzeyi ve öykü formuna yönelik soruların ve cevaplama alanlarının yer aldığı araştırmacının kullanımı için hazırlanmış bir kay1t formudur (Karasu, 2011; Karasu; Girgin ve Uzuner, 2013).

\section{Değerlendirmeciler arası güvenirlik}

$\mathrm{Bu}$ araştırma kapsamında elde edilen verilere yönelik değerlendirmeciler arası güvenirlik hesaplanmıştır. Değerlendirmeciler arası güvenirlik verilerinin hesaplanabilmesi için temel eğitim bölümünde görev yapan ve sınıf eğitimi alanında doktora eğitimine devam eden bir değerlendirmeci belirlenmiştir. Değerlendirmeci, okuma becerileri ile ilgili lisans ve lisansüstü eğitiminde ders almıştır. Araştırmacı, değerlendirmeciye, çalışma grubundan olmayan bir öğrencinin verileri ile okuma hataları, okuma hata türlerinin belirlenmesi ve okuduğunu anlama sorularının puanlanması alanlarında eğitim vermiştir. Eğitim sürecinde araştırmacı öncelikle değerlendirmeciye model olmuş; daha sonra değerlendirmeciyle birlikte analizler gerçekleştirilmiştir. Değerlendirmeciler arası güvenirlik verilerinin hesaplanması öncesinde araştırmacı ve değerlendirmeci arasındaki uyum yüzdesi yine çalışma grubuna dâhil edilmeyen öğrencilerin verileri üzerinden hesaplanmıştır. Üç oturum üst üste $\% 80$ ve üzeri ölçümlendiğinde, araştırmacı seçkisiz bir şekilde az gören ve gören öğrencilerin \%30'unun (3 az gören ve 3 gören öğrenci) ses kayıtlarını ve değerlendirme formlarını değerlendirmeciye vermiş ve değerlendirmesini istemiştir. Gözlemci, değerlendirmelerini tamamladıktan sonra veriler arasındaki uyum yüzdesi hesaplanmıştır. Uyum yüzdeleri sözdizimi kabul edilebilirliğinde $\% 87,3$ (\%82,7-91,3); anlam kabul edilebilirliğinde \%85,5 (\%80,3-\%88,9); yazarın iletmek 
istediği anlamın değişmesi alanında \%89,1 (\%83,6-\%93,4); harf ses benzerliklerinde \%91,2 $(\% 86,2-\% 95,3)$; okuduğunu anlamada \%87,6 $(\% 83,4-\% 92,9)$ olarak hesaplanmıştır.

\section{Verilerin toplanması}

Öğrencilerle yapılan değerlendirmeler içinde masa ve iki sandalye bulunan odalarda birebir olarak gerçekleştirilmiştir. Verileri toplamadan önce az gören öğrenciler için mekânsal ve görme durumlarına göre öykü yazılarında uyarlamalar yapılmıştır.

İlk olarak az gören öğrencilerin bireysel ihtiyaçları doğrultusunda öğrenci tercihleri ve öğretmen görüşleri de dikkate alınarak sandalye ve masanın oda içerisindeki konumu, 1şıklandırma durumu (oda lambası, gün ışığı veya masa lambası) ile ilgili mekânsal düzenlemeler gerçekleştirilmiştir.

Öğrenciye okutulacak öykünün punto büyüklüklerinin belirlenmesi için, 1,5 satır aralığında yazılmış $16,18,20,24$ punto büyüklügünde ders kitaplarından alınmış öykü bölümleri hazırlanmıştır. Her sınıf düzeyinde, her punto büyüklügü için farklı öykülerden yararlanılarak, tekrarlı okumanın etkisi ortadan kaldırılarak, uygun punto büyüklüğünün belirlenmesinin güvenilir bir şekilde gerçekleştirilmesi amaçlanmıştır. Bir sayfayı geçmeyen öykünün bütünlüğünü bozmayacak şekilde bir öykü bölümü yazılmıştır. Araştırmacı her punto düzeyinde öğrencilere öyküleri okutmuş ve tüm metinlerin okunması tamamlanınca, öğrencilerin okuma süresince görme davranışlarını, metnin yazılı olduğu kâğıtla öğrencinin etkileşimini (örneğin, kâğıdı göze çok fazla yaklaştırma ve göz ile kâğıt arasında mesafenin kalmaması), öğrencinin okuma akıcılığını ve öğrencinin genel zorlanım durumunu bütüncül (holistic approach) bir şekilde irdeleyerek uygun punto büyüklügüne karar vermiştir. Az gören öğrencinin uygun punto büyüklüğünü belirlendikten sonra, öğrenci için uygun olan satır aralığının belirlenme sürecine başlanmıştır. Bu amaçla öğrencilere, okuyabildikleri uygun punto büyüklüğünde yazılmış, 1,5 ve 2 satır aralığında yazılmış öykü parçaları sırayla okutularak, punto büyüklüğünde olduğu gibi uygun satır aralığı belirlenmiştir. Ayrıca, öğretmenlere uygulanan bilgi formlarında, öğrencinin okumasına yönelik belirtilen diğer uyarlamalar da araştırmacı tarafından gerçekleştirilmiştir. Az gören öğrenciler, görme aracı kullanıyorlarsa, araştırmacı tarafından uygulama sürecinde de kullanmalarına izin verilmiştir.

Değerlendirme süreci birinci araştırmacı tarafindan her bir öğrenci için tek oturumda ve birebir gerçekleştirilmiştir. FOOE'nde yer alan ilgili sınıf düzeyine ait A formu öykü hem öğrencinin hem de araştırmacının önünde yer almıştır. Araştırmacı, öğrencilere okumalarının ses kaydının alınacağını söylemiş ve isterlerse ses kayıt cihazını inceleyebileceklerini söylemiştir. Sonra, araştırmacı yönergesini "Önündeki öyküyü en güzel okumanla sesli olarak oku" diyerek vermiştir. Öğrenci okurken, araştırmacı okuma hatalarını kendi önündeki öykü üzerinden işaretlemiştir. Öğrenci sesli okumasını bitirince araştırmacı "Şimdi bir kere de önündeki öyküyü içinden oku okumandan sonra sana okuduğu anlam soruları soracağım" diyerek yönergesini vermiştir. Öğrenci içinden okumasını da bitirince araştırmacı okuduğunu anlama sorularını sözel olarak sorup öğrencilerin verdikleri cevapları önündeki forma kaydetmiştir.

\section{Hata analizi}

Hata analizi, okuyucuların sesli okumaları sırasında yaptıkları okuma hatalarını analiz ederek yazılı materyali bilişsel olarak nasıl işlemlediklerini belirleyebilmek için faydalanılan bir analiz yöntemidir (Wixson, 1979). Hata analizinde, dilin ipucu sistemleri analiz edilerek okuyucunun hataları ile ilgili derinlemesine bilgi edinilir. Dilin ipucu sistemlerinin analizi kapsamında söz dizimi kabul edilebilirliği yüzdesi, anlam kabul edilebilirliği yüzdesi, yazarın iletmek istediği düşüncenin değişme yüzdesi ve harf ses benzerliği yüzdesi hesaplanmıştır (bkz. Karasu, 2011).

Söz dizimi kabul edilebilirliğinin analizi kapsamında, öğrencinin gerçekleştirdiği okuma hatasının Türk dilinin söz dizimi özelliklerini bozup bozmadığı değerlendirilmiştir. Öğrencinin yaptığı bir okuma hatası cümlenin Türk dilinin sözdizimi özelliklerini bozmuyorsa "evet", bozuyorsa "hayır" şeklinde kodlanmıştır. Anlam kabul edilebilirliğinin analizinde sergilenen bir okuma hatasının cümlenin anlamını değiştirip değiştirmediği analiz edilir. Hata cümlenin 
anlamını değiştirmiyorsa "Evet", değiştiriyorsa "Hayır" olarak kodlanmıştır. Yazarın iletmek istediği mesajı iletilmesinin değerlendirilmesinde cümlenin anlamı ile yazarın iletmek istediği anlamın uyuşup uyuşmadığı analiz edilir. Anlam bakımından değişmiş cümle sayısını hesaplayabilmek için okuma hatası cümleyi anlam bakımından değiştiriyorsa "Evet", değiştirmiyorsa "Hayır" olarak kodlanır. Harf-ses benzerliğinin analizinde, söz dizimi ve anlam kabul edilebilirliği "Hayır" olarak kodlanan hatalar incelemeye alınmaz; "Evet" olarak kodlanan hatalar harf ses benzerliği açısından incelenir. Hatalı olarak okunan sözcükteki harflerden bir ya da ikisi hatalı okunduysa benzerlik yüksek, iki-üç harf farklı ise orta, benzerlik bulunmuyorsa “yok" olarak kodlanmıştır (bkz. Davenport, 2002; Karasu 2011).

Aşağıda dilin ipucu sistemlerinin yüzde hesaplama formüllerine yer verilmiştir.

Söz dizimi kabul edilebilirliği yüzdesi: Sözdizimi Doğru Kabul Edilen Cümle Sayısı / Toplam Cümle Sayısı x 100 formülüyle; Anlam Kabul Edilebilirliği Yüzdesi: Anlamı Doğru Kabul Edilen Cümle Sayısı / Toplam Cümle Sayısı x 100 formülüyle; Yazarın İletmek İstediği Düşüncenin Değişme Yüzdesi: Anlam Bakımından Değişmiş Cümle Sayısı / Toplam Cümle Sayıs1 x 100 formülüyle;Yüksek Harf Ses Benzerlikleri Yüzdesi: Yüksek Harf Ses Benzerliği/Toplam Harf Ses Benzerliği x 100; Orta Harf Ses Benzerliği Yüzdesi: Orta Harf Ses Benzerliği/Toplam Harf Ses Benzerliği x 100 formülleri ile hesaplanmıştır.

\section{Okuduğunu anlama sorularına verilen cevapların analizi}

Okuduğunu anlama soruları her sınıf düzeyinde 100 puan üzerinden değerlendirilmiştir. Her sınıf düzeyi için sorulan 10 sorunun her biri 10 puanüzerinden değerlendirilmiştir. Öğrencilerin verdikleri cevapların değerlendirilmesinde, metinsel açık sorular öğrencinin verdiği cevabın metindeki ile bire bir aynı olması ya da anlamlarının aynı olması durumunda tam puanla puanlanmıştır. Öğrenci cevabın yarısını vermiş ya da cevabın yarısı doğru yarısı yanlış ise tam puanın yarısı verilmiştir. Cevabın ağırlıklı bir kısmı yanlış ve metindeki bilgiye yönelik yalnız bir kelime içermekteyse, bu cevaplara 2 puan verilmiştir. Metinsel açık sorularınpuanlamasında, doğru cevap dört veya daha fazla olay ya da bilgiden oluşuyor ise öğrencinin hepsini ya da bir eksiğini belirtmesi tam puan; yarısını söylemesi verilecek puan değerinin yarısı ve yalnız birini belirtmesi 2 puanla değerlendirilmiştir. Öğrencinin cevabı, doğru cevabın hiçbir unsurunu içermiyorsa 0 punla değerlendirilmiştir (Karasu, 2011).

Metinsel kapalı soruların(cevabı metnin içinde olan, lakin doğrudan bulunmayan soru tipleri) tek tip bir cevabı bulunmayabilmektedir. Bu nedenle, ögrenci, metindeki bilgi birimlerini içerecek şekilde cevap verdiyse tam puan; doğrudan ve açık bir şekilde belirtemediyse tam puan değerinin yarısı verilmiştir. Sorulan soruya verilen cevap, metinle ilgili olmakla birlikte, soru ile ilişkili değilse, 0 puan verilmiştir (Karasu, 2011).

Bilgi ve deneyim sorularına verilen cevaplar değerlendirilirken, öğrenci metindeki olay ya da bilgi ile kendi birikimlerini birleştirip cevap veriyorsa tam puan verilmiştir. Cevap metinle ilişkiyi içermiyorsa 0 puan verilmiştir. Anlamı değiştirmeyen hatalarda puan azaltılması yapılmamıştır. Verilerin analizinde nitel analiz yönteminden faydalanılmıştır. Nitel analiz ile öğrencilerin dilin ipucu sistemlerinden aldıkları yüzde değerleri ve okuduğunu anlama düzeyleri eş güdümlü şekilde analiz edilmiştir.

\section{Bulgular}

Tablo 3'te gören öğrencilerin dilin ipucu sistemlerini kullanma yüzdeleri sunulmuştur. Tablo 3 incelendiğinde gören öğrencilerin okuduğunu anlama puan düzeylerinin 60-95 aralığında olduğu görülmektedir. Gören öğrencilerin okuduğunu anlama puanları incelendiğinde Tablo 3'e göre 80-100 puan aralığında 5 öğrenci bulunmaktadır. Gören öğrencilerin söz dizimi kabul edilebilirliği $\% 85-\% 100$; anlam kabul edilebilirliği \%81-\%100; anlamı değiştiren hata yüzdesi $\% 0-\% 8$ arasındadır. Gören öğrencilerin yaptıkları okuma hatalarındaki harf ses benzerliklerinin $\% 71$ ile -\%100 aralı̆̆ında yüksek; \%0 ile \%20 aralığında orta düzeydedir. Gören öğrencilerin okuma hatalarının \%0 ile \%9'aralığında harf ses benzerliği bulunmamaktadır.

Tablo 3'de görüldüğü gibi 7 ve 9. öğrencilerin söz dizimi kabul edilebilirliği ve anlam kabul edilebilirliği \%100 olup, anlamı değiştiren hata yapmamışlardır. 9. öğrencinin harf ses 
benzerliği $\% 97$ oranında yüksek, \%3 oranında orta düzeydedir. 7. öğrencinin ise harf ses benzerliği \%100 oranında yüksek bulunmuştur. 8. öğrenci incelendiğinde ise, bu öğrencinin herhangi bir hata yapmadığı bulunmuştur. Dolayısı ile bu öğrenci için bir hata analizi süreci gerçekleştirilmemiştir. 7,8 ve 9 numaralı öğrencilerin okuma hatalarındaki performansları öğrencilerin okuduğunu anlamalarına yansımış bu öğrenciler sorulara doğru cevap verme oranı en yüksek üç öğrenci olmuşlardır. 3. öğrencinin bulguları 7, 8 ve 9. öğrenciye benzemekle beraber bu öğrencinin anlamı değiştiren hata yüzdesi \%4 olarak bulunmuştur. Okuduğunu anlama puanı ise 7,8 ve 9 . öğrencilere göre daha düşük bir değer olan 70 olarak hesaplanmıştır.

Tablo 3 incelendiğinde, gören katılımcilardan okuma hatalarının söz dizimi ve anlam kabul edilebilirliği en düşük olan öğrenciler 1 ve 2 . öğrencilerdir. $\mathrm{Bu}$ öğrencilerin harf ses benzerlikleri de diğer gören öğrencilere göre en düşük düzeyde olduğu belirtilebilir. Bu öğrencilerin okuduğunu anlama puanlarının 60 ve 62 olduğu görülmektedir. Bu okuduğunu anlama puanları gören öğrencilerin bulunduğu çalışma grubunun en düşük iki okuduğunu anlama puanıdır. Dolayısıyla okuma hataları öğrencilerin okuduğunu anlama puanlarına yansımıştır. 
Tablo 3.

Gören Öğrencilerin Dilin İpucu Sistemlerini Kullanma Yüzdeleri ve Sorulara Cevap Verme Puanları

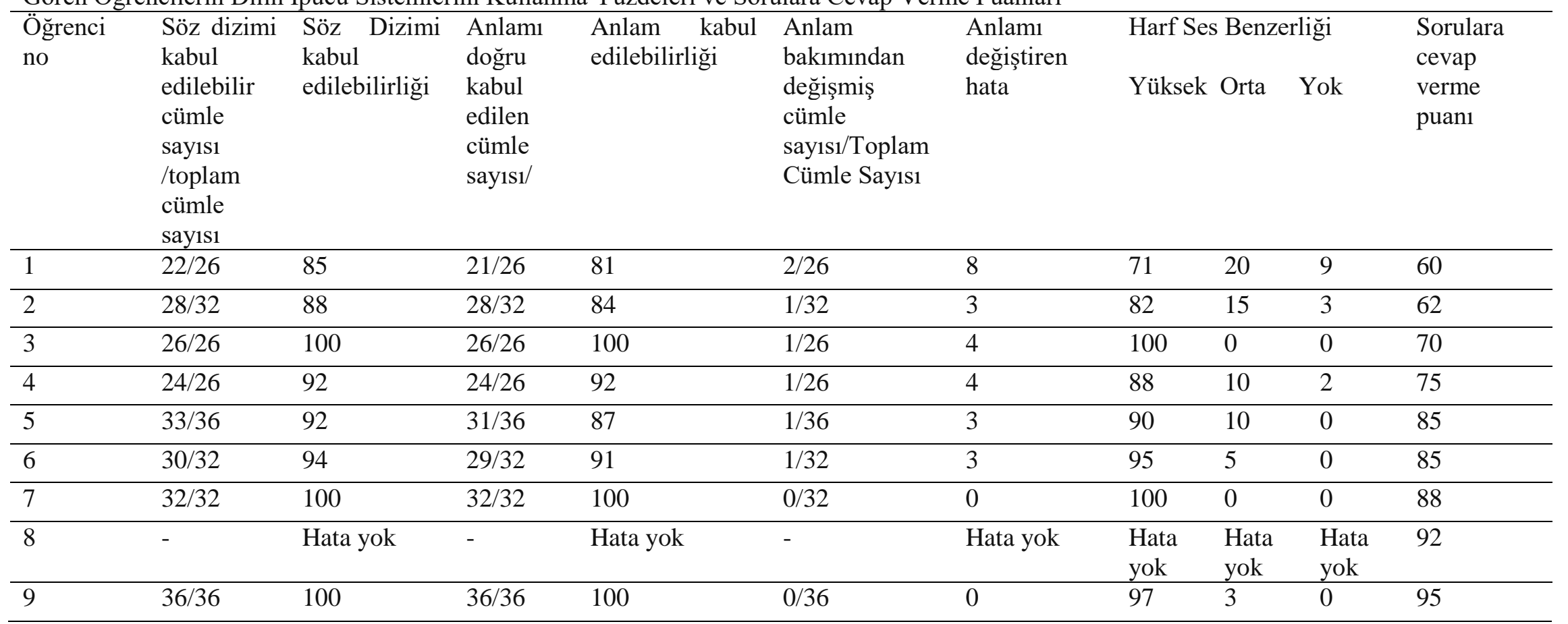

Tablo 4'de az gören öğrencilerin dilin ipucu sistemlerini kullanma yüzdeleri sunulmuştur. 
Tablo 4.

Az Gören Öğrencilerin Dilin İpucu Sistemlerini Kullanma Yüzdeleri

\begin{tabular}{|c|c|c|c|c|c|c|c|c|c|c|}
\hline $\begin{array}{l}\text { Öğrenci } \\
\text { no }\end{array}$ & $\begin{array}{l}\text { Söz Dizimi } \\
\text { kabul } \\
\text { edilebilirliği }\end{array}$ & $\begin{array}{l}\text { Söz } \\
\text { dizimi } \\
\text { kabul } \\
\text { edilebilir } \\
\text { cümle } \\
\text { sayis1 } \\
\text { /toplam } \\
\text { cümle } \\
\text { say1s1 }\end{array}$ & $\begin{array}{l}\text { Anlam kabul } \\
\text { edilebilirliği }\end{array}$ & $\begin{array}{l}\text { Anlamı } \\
\text { doğru } \\
\text { kabul } \\
\text { edilen } \\
\text { cümle } \\
\text { sayısi/ }\end{array}$ & $\begin{array}{l}\text { Anlami } \\
\text { değiştiren } \\
\text { hata }\end{array}$ & $\begin{array}{l}\text { Anlam } \\
\text { bakıııından } \\
\text { değişmiş cümle } \\
\text { sayıs//Toplam } \\
\text { Cümle Sayısı }\end{array}$ & Harf Ses & Benz & zerliği & $\begin{array}{l}\text { Okuduğunu } \\
\text { anlama puanı }\end{array}$ \\
\hline 10 & 53 & $19 / 36$ & 50 & $18 / 36$ & 22 & $8 / 36$ & 52 & 20 & 28 & 57 \\
\hline 11 & 81 & $29 / 36$ & 78 & $28 / 36$ & 17 & $6 / 36$ & 64 & 30 & 6 & 62 \\
\hline 12 & 73 & $19 / 26$ & 50 & $13 / 26$ & 35 & $9 / 26$ & 47 & 30 & 23 & 65 \\
\hline 13 & 100 & $26 / 26$ & 100 & $26 / 26$ & 8 & $2 / 26$ & 89 & 9 & 2 & 70 \\
\hline 14 & 85 & $22 / 26$ & 85 & $22 / 26$ & 19 & $5 / 26$ & 72 & 15 & 13 & 77 \\
\hline 15 & 91 & $29 / 32$ & 72 & $23 / 32$ & 13 & $4 / 32$ & 84 & 6 & 10 & 85 \\
\hline 16 & 88 & $28 / 32$ & 88 & $28 / 32$ & 0 & $0 / 32$ & 100 & 0 & 0 & 85 \\
\hline 17 & 100 & $36 / 36$ & 100 & $36 / 36$ & 0 & $0 / 36$ & 97 & 3 & 0 & 90 \\
\hline 18 & 97 & $31 / 32$ & 94 & $30 / 32$ & 3 & $1 / 32$ & 100 & 0 & 0 & 92 \\
\hline
\end{tabular}


Tablo 4 incelendiğinde az gören öğrencilerin okuduğunu anlama puan düzeylerinin 5792 aralığında olduğu görülmektedir. Bu öğrenciler arasında okuduğunu anlama puanı 80-100 puan aralığında olan dört öğrenci bulunmaktadır. Az gören öğrencilerin söz dizimi kabul edilebilirliği \%53-\%100 arasında anlam kabul edilebilirliği \%50-\%100 arasında değişmektedir. $\mathrm{Az}$ gören öğrencilerin anlamı değiştiren hata yüzdesi $\% 0-\% 35$ ranjındadır. Az gören öğrencilerin yaptıkları okuma hatalarındaki harf ses benzerliklerinin \%47-\%100'ü yüksek; \%0$\% 30$ 'u orta düzeydedir. Az gören öğrencilerin okuma hatalarının \%0-\%28'inde ise harf ses benzerliği yoktur.

Tablo 4'te görüldüğg̈ gibi katılımcılar arasında okuma hatası olmayan az gören öğrenci bulunmamaktadır. 17 ve 18. ögrenciler incelendiğinde sırasıyla, söz dizimi kabul edilebilirliği $\% 100$ ve $\% 97$, anlam kabul edilebilirlikleri $\% 100$ ve \%94 olarak bulunmuştur. Bu öğrencilerin harf-ses benzerlikleri \%97 ve \%100 oranında yüksektir. En yüksek anlama puanlarına da bu öğrenciler sahiptir.

En düşük okuduğunu anlama puanını alan 10. öğrenci incelendiğinde; bu öğrencinin söz dizimi kabul edilebilirliği ve anlam kabul edilebilirliği puanlarının sırasıyla $\% 53$ ve $\% 50$ bulunduğu görülmektedir. Tablo 4 incelendiğinde, bu değerlerin az gören öğrenci grubu içerisindeki en düşük puanlar olduğu belirtilebilir. Bu öğrencinin anlama puanı da öğrenciler arasında en düşüktür.

13. öğrenci incelendiğinde, bu öğrencinin söz dizimi kabul edilebilirliğinin ve anlam kabul edilebilirliği yüzdesinin \% 100 olduğu görülmektedir. 13. ile 17.öğrenci arasındaki fark 17. öğrencinin lehine anlamı değiştiren hata yüzdesi ile harf ses benzerliğidir. 13. öğrenci aynı söz dizimi kabul edilebilirliği ve anlam kabul edilebilirliği oranına sahip olan 17. öğrenciden okuduğunu anlamada daha düşük puan almıştır.

Sonuç olarak söz dizimi ve anlam kabul edilebilirliği bakımından az gören öğrenciler arasından gören öğrencilere göre daha düşük yüzdelikte puan alanlar bulunmaktadır. Aynı durum anlamı değiştiren hata yüzdesi, harf ses benzerliği ve okuduğunu anlama puanları için de gözlenmiştir.

\section{Tartışma, Sonuç ve Öneriler}

$\mathrm{Bu}$ araştırmada, az gören ve gören öğrencilerin okuma hataları hata analizi yöntemi ile analiz edilmesi ve okuduğunu anlama becerisine yansımasının belirlenmesi amaçlanmıştır. Araştırma bulguları incelendiğinde, az gören öğrencilerin dilin ipucu sistemlerini kullanmada gören öğrencilere göre daha sınırlı becerilere sahip oldukları belirtilebilir. Söz dizimi kabul edilebilirliği, anlam kabul edilebilirliği ve anlamı değiştiren hatalarla ilgili bulgular incelendiğinde az gören öğrencilerin okuma hatalarının söz dizimi kabul edilebilirliğinin, anlam kabul edilebilirliği yüzdelerinin daha düşük; anlamı değiştiren hata yüzdelerinin ise daha yüksek olduğu görülmektedir. Harf ses benzerliklerinde ise az gören öğrencilerin harf ses benzerliklerinin daha düşük oldukları bulunurken, gören öğrencilerin harf ses benzerliklerinin daha yüksek olduğu bulunmuştur. Bununla beraber, az gören öğrencilerin bazılarının, gören öğrencilere benzer hatta gören öğrencilerden daha iyi dilin ipucu sistemlerini kullanabildikleri görülmektedir. Bu durum az gören öğrencilerin heterojenliğiyle açılanabilir. Marmion (2012) bu heterojenliğe vurgu yaparak, az gören öğrencilerin görsel performanslarından ve bireysel etmenlerinden dolayı farklı görsel işlevde bulunduklarını belirtmiştir.

Az gören öğrencilerde dilin ipucu sistemlerini kullanmada kabartma yazı ile beraber gören yazıyı kullanan öğrencilerin performanslarının daha düşük olduğu gözlemlenmiştir (10 ve 12 numaralı öğrenciler). Bu durum, hem gören yazı hem de kabartma kullanan öğrencilerin yalnızca gören yazı kullanan akranlarına göre gören yazıya daha az vakit ayırmalarından kaynaklanabilir.

Katılımcıların sınıf düzeylerine göre okuma hataları incelendiğinde 5. sınıfta okuyan gören öğrencilerin (17 ve 18. öğrenciler) ağırlıklı olarak dilin ipucu sistemlerini kullanmada daha yetkin olduğu görülürken; az gören öğrenci grubunda dilin ipucu sistemlerini kullanmada güçlük yaşayan öğrencilerin (1 ve 2. öğrenciler) ağırlıklı olarak 5. sınıf düzeyinde olduğu görülmektedir. Bu durum Matthew etkisi (Matthew effect) ile açılanabilir. Matthew etkisi 
sosyolojide, zamanla zenginin daha zengin fakirin daha fakir olması durumu ile açıklanmaktadır. Eğitim alanında ise Matthew etkisi performansı yüksek olan öğrencilerin ileriki dönemlerde performansının daha da artacağı, düşük olan öğrencilerin ise daha da düşeceği şeklinde ele alınır. Bu araştırmada da 5. sınıf düzeyindeki gören öğrencilerin ağırlıklı olarak daha yüksek bir performans sergilediği bulunurken; az gören öğrencilerin 5. sınıf düzeyinde daha düşük performans sergilediği bulunmuştur.

$\mathrm{Az}$ gören öğrencilerin okudukları punto büyüklüklerine göre okuma hataları incelendiğinde 18-20 punto büyüklüğündeki öyküleri okuyan öğrencilerin(15, 16 ve 18. öğrenciler) ağırlıklı olarak okuma performanslarının daha yükssek olduğu gözlemlenmiştir. 16 (10 ve 12. öğrenciler) ve 24 punto (11 ve 14. öğrenciler) büyüklüğündeki öyküleri okuyan öğrencilerin ise okuma performanslarının daha düşük olduğu belirtilebilir. 16 puntonun en düşük punto değeri olması öğrencilerin dikkatlerini dilin ipucu sistemlerinden çok çözümlemeye odaklanmalarıyla; 24 puntonun ise en yüksek punto değeri olması ögrencilerin sözcükleri ve cümleleri bir bütünlük halinde işlemleyememesi ile açıklanabilir.

$\mathrm{Az}$ gören öğrencilerin yalnızca üçü okurken görme aracı kullanmıştır(10, 12 ve 16. öğrenciler). Görme aracı kullanan öğrencilerin okuma hatalarının heterojen bir yapıda olduğu belirtilebilir. Bu noktada görme aracının tek başına okuma performansı üzerine olumlu ya da olumsuz etki yapmayabilir. Bu çalışmada sınıf düzeyi, punto, gören yazı ve kabartma yazı kullanımı gibi hem yazımın sunumunu içeren materyal hem de eğitim geçmişi öğrencilerin okuma performansını etkilemiştir.

Az gören öğrencilerin kullandıkları dilin ipucu sitemleri ile gören öğrencilerinki benzeşmekle beraber oranlara bakıldığında dilin ipucu sistemlerini kullanma oranları ağırlıklı olarak gören öğrencilere göre daha düşüktür. Bu sonuç ile ilgili belirtilebilecek gerekçeler arasında görme becerilerindeki sınırlılık, okuma materyaline erişmede ve okuma materyali ile yaşantı kurmada gören akranlara göre oluşabilecek dezavantajlar belirtilebilir.

$\mathrm{Bu}$ araştırmada elde edilen diğer bir bulgu ise az gören öğrencilerin "yüksek" harf ses benzerliği oranının gören öğrencilere göre daha düşük olmasıdır. Bu bulgular Dougles'ın (2002) bulguları ile benzerlik göstermektedir. Dougles yaptığı çalışmada 6-12 yaş aralığındaki az gören öğrencilerin okuma hatalarının akranlarına göre daha yüksek olduğunu bulmuştur. Az görme durumu, doğası gereği, görmenin farklı boyutlarında sınırlılık içerdiği için, az gören ögrencilerin okuma hatalarında harf ses benzerliği düşük düzeyde olabilmektedir.

Her iki grupöğrencide de okuma hataları anlamaya yansımıştır.Az gören öğrencilerden anlamı değiştiren hataları daha fazla yapanların ve harf ses benzerlikleri düşük olan öğrencilerin okuduğunu anlamalarının daha düşük olma eğilimindedir. Anlamı değiştiren hatalar, yazarın iletmek istediği anlamı bozan hatalardır. Yazarın iletmek istediği mesajın okuyucu tarafından daha az anlaşı1ır olması, okuyucunun okuduğunu anlamasını da etkileyebilecektir. Anlamanın ilk basamağının kod çözme ya da çözümleme olduğu dikkate alındığında; bu aşamada gerçekleşebilecek problemler harf ses benzerliğinin düşük olmasına yol açabilecektir. Harf-ses benzerliğinin düşük olması kelimenin doğru bir şekilde sesletilmesini engellediğinden, okuduğunu anlamanın önünde bir bariyer olabilmektedir.

Sonuç olarak, az gören öğrencilerin okuma hatalarının hata analizi ile incelenmesi okuma hatalarına ilişkin derinlemesine bilgi sağlamaktadır. İleride az gören öğrencilerle yapılacak okuma çalışmalarında hata analizinin kullanılması az gören öğrencilerin okuma performanslarına ilişkin var olan durumu ortaya koyması ve uygun müdahalelerin desenlenmesi açısından önemlidir. İleri araştırmalarda, katılımcı sayısı arttırılarak daha geniş örneklemler ile araştırma tekrarlanabilir. Bu araştırmada görme yetersizliği olan öğrenci grubundan az gören ögrenciler ile çalışılmıştır. Daha sonra gerçekleştirilecek araştırmalarda Braille ile okuyup yazan öğrencilerin gerçekleştirdikleri okuma hataları hata analizi ile incelenebilir. 


\section{Katkısı Olanlar}

Araştırmanın 1. yazarı TUBİTAK 2211A Yurt içi doktora bursu kapsamında desteklenmiştir ve TUBİTAK'a teşekkür etmektedir.

\section{Kaynaklar}

Akyol, H. (2007). Türkçe ilk okuma yazma ögretimi. Ankara: Pegem..

Armbruster, B. B., Lehr, F., ve Osborn, J. (2001). Put reading first (3rd ed.). Washington, DC: National Institute for Literacy. Erişim adresi: staff.gvsu.edu/FISHERJ/3.Put\% 20Reading\%20First\%20Handout.pdf

Baltacı, A. (2018). Nitel araştırmalarda örnekleme yöntemleri ve örnek hacmi sorunsalı üzerine kavramsal bir inceleme. Bitlis Eren Üniversitesi Sosyal Bilimler Enstitüsü Dergisi, 7(1), 231-274.

Corley, G. ve Pring, L. (1993a). Reading strategies in partially sighted children. International Journal of Rehabilitation Research, 16(3), 209-220.

Corley, G. ve Pring, L. (1993b). The oral reading errors of partially sighted students. International Journal of Rehabilitation Research, 16(3), 209-220.

Çakmak, S., Karakoç, T., Şafak, P. ve Kan, A. (2014). Identifying the reading speed of low vision student's at elementary level. International Journal in IT \& Engineering, 2(10), $38-48$.

Davenport, M. R. (2002). Miscues not mistakes: Reading assessment in the classroom. Portsmouth: Heinemann.

Douglas, G., Grimley, M., Hill, E., Long, R. ve Tobin, M. (2002). The use of the NARA for assessing the reading ability of children with low vision. British Journal of Visual Impairment, 20(2), 68-75.

Douglas, G., Grimley, M., McLinden, M. ve Watson, L. (2004). Reading errors made by children with low vision. Ophthalmic and physiological optics, 24(4), 319-322.

Epçaçan, C. (2009). Okuduğunu anlama stratejilerine genel bir bakış. Journal of International Social Research, 1(6), 207-223.

Fellenius, K. (1999). Swedish 9-year-old readers with visual impairments: a heterogeneous group. Journal Of Visual Impairment \& Blindness, 93(6), 370-380.

Goodman, K. S. (1969). Analysis of reading miscues: Applied psycholinguistics. Reading Research Quarterly, 5, 9-30.

Güzel, R. (1998). Alt özel sinıflardaki öğrencilerin sesli okudukları öğrencilerin sesli okudukları öyküyü anlama becerisini kazanmalarında doğrudan ögretim yöntemiyle sunulan bireyselleştirilmiş okuduğunu anlama materyalinin etkililiği (Yayımlanmamış doktora tezi). Gazi Üniversitesi Eğitim Bilimleri Enstitüsü, Ankara.

Güzel-Özmen, R. (2013). Okuma öğretimi. İ. H. Diken (ed.), İlköğretimde kaynaştırma içinde (ss. 362-401). Ankara: Pegem Akademi.

Harris, P. (2007). Behavioral Vision Care. Erişim adresi: www.oepf.org/VTAids/Behavioral $\% 20$ Vision\%20Care\%20Info.pdf

Karasu, H. P. (2011). Isşitme engelli öğrenciler ve işiten öğrencilerin okuma becerilerinin formel olmayan okuma envanteri ile değerlendirilmesi (Yayımlanmamış doktora tezi). Anadolu Üniversitesi Eğitim Bilimleri Enstitüsü, Eskişehir.

Karasu, H. P., Girgin, Ü. ve Uzuner, Y. (2013). Formel olmayan okuma envanteri. Ankara: Nobel.

Labov, W. ve Baker, B. (2010) What is a reading error?, Applied Psycholinguistics, 31(4), 735757.

McKenna, M. C. ve Picard, M. C. (2006). Revisiting the role of miscue analysis in effective teaching. The Reading Teacher, 60, 378-380.

Maples, W. C. (2003). Visual factors that significantly impact academic performance. Optometry-st Louis, 74(1), 35-49. 
Marmion, S. (2012). Low vision performance as a function of task characteristics. G. C. Woo (Yay. haz.). Low vision: Principles and applications. Proceedings of the International içinde (s. 490-500). Erişim adresi: books.google.com.tr/

Öz, F. (2006). Uygulamalı Türkçe ögretimi. Ankara: Anı Yayımcılık.

Serino, L. K. L. (2007). The effect of repeated reading with middle school students with visual impairments. USA: ProQuest Information and Learning Company.

Tuncer, A. T. (2003). Görme yetersizliği olan çocuklar. A. Ataman (Ed.). Özel eğitime giriş içinde (s. 293-311). Ankara: Gündüz Eğitim ve Yayıncılık.

van Bon, W., Adriaansen, L., Gompel, M. ve Kouwenberg, I. (2000). The reading and spelling performance of visually impaired Dutch elementary school children. Visual Impairment Research, 2(1), 17-31.

Wixson, K. L. (1979). Miscue Analysis: A Critical Review. Journal of Reading Behavior, 11(2), 163-175. https://doi.org/10.1080/10862967909547319

Yıldırım, A. (1999). Nitel araştırma yöntemlerinin temel özellikleri ve eğitim araştırmalarındaki yeri ve önemi. Eğitim ve Bilim, 23(112).

\section{Extended Abstract}

\section{Introduction}

Reading skill is an important skill in terms of providing a primary source for learning experiences in school (Güzel-Özmen, 2013). When the components of reading skill are examined, it is seen as a multi-layered and gradual skill. Armbruster, Lehr and Osborn (2001) stated that reading skills consist of phonological awareness, reading fluency, vocabulary and reading comprehension; systematic reading interventions to be performed should be based on these elements of reading. . The ultimate aim of systematic interventions on the elements of reading is that the student can come to the stage where he can derive meaning from the text he read (Epçaçan, 2009).

Behavioral optometry, which emphasizes that the effective use of the existing vision, will affect the visual behaviors such as reading and writing positively and improve the use of the existing vision, leads to the interventions to use the vision (Harris, 2007). Maples (2003), one of the researchers working in this field, examined the changing effects of ethnicity, socioeconomic level and sense of vision on academic achievement in her descriptive research conducted with elementary school students in the USA. Although the effect of ethnicity and socioeconomic level on academic achievement was significant; The most significant effect on academic achievement is due to limitations in visual perception.

In studies related to reading performance of students with low vision, it was found that reading errors of students with low vision were higher than their peers (Douglas et al., 2002; Douglas et al., 2004). In some studies, there is evidence that low vision students have more limited reading performance than their peers (Corley \& Pring, 1993a, 1993b; Fellenius, 1999). In the literature, although there are predominant views on the limitation of reading skills of low vision students, there are also some studies showing that low vision students have the same or better level of reading performance as their peers (van Bon, Adriaanses, Gompel \& Kouwenberg, 2000).

Reading errors have an informative role for teachers, their students' reading comprehension skills and their problems in analysis (Goodman, 1969; McKenna \& Picard, 2006). Reading errors therefore provide important data for teachers to organize appropriate interventions. Comprehensive information can be gathered on reading errors and readers' use of the clue systems of thought and language (semantics, syntax, syntax, and letter-sound relationship) (Davenport, 2002) and comprehension processes.

The aim of this study is to examine the reading errors of students with low vision and sighted students by low vision. 


\section{Method}

In this study, qualitative research model was used to investigate reading errors in story type texts of low vision students and visual students. Qualitative research is a model based on systematic and logical response to a particular problem (Yıldırım, 1999).

Nine sighted students, three in each of the 3, 4 and 5 grade levels attending primary and secondary schools for visually impaired students, and nine sighted students in each of 3, 4 and 5 grade levels in primary and secondary schools where sighted students continue.

Some prerequisites have been determined in the selection process of low vision students. These prerequisites are: a) to use visual writing (printed Turkish alphabet) in the process of reading and writing, b) they do not have any additional deficiencies other than low vision, and c) have the ability to decoding. Some prerequisites have also been set for sighted children. These prerequisites are: a) they do not have any deficiencies and b) they have the ability to decoding.

Two information forms were developed by the researchers in order to obtain information for students with low vision and sighted students within the scope of this research. These forms are "Low Vision Student Information Form" and "Vision Student Information Form" developed for teachers to fill out. These forms include questions about reading skills as well as demographic information of the students. The Low Vision Student Information Form also includes questions about the visual status of students with low vision (whether they have any visual aids, etc.).

The data collection tools used in the evaluation of reading errors are stories, miscue analysis forms and question/answer forms which was developed by Karasu (2011).

The evaluation process was carried out in a single session. The Form A story of the relevant grade in the FOOE was in front of both the student and the researcher. The researcher told the students that their readings would be recorded and that they could examine the sound recorder if they wanted. Then, the researcher gave his instruction saying "Read the story in front of you with the most beautiful reading aloud". While the student was reading, the researcher marked the reading errors through the story in front of him. When the student finished reading aloud, the researcher gave the directive saying "Now once you read the story silently in front of you, then I will ask you comprehension questions". When the student finished reading, the researcher asked the comprehension questions and recorded the answers in the form in front of him.

After collecting data, miscue analysis was performed. Miscue analysis is an analysis method used to determine how readers process written material cognitively by analyzing the reading errors made by the readers during their audio readings (Wixson, 1979). In the miscue analysis, the clue systems of the language are analyzed and in-depth information about the errors of the reader is obtained. In the analysis of the clue systems of the language, the percentage of syntactic acceptability, the percentage of meaning acceptability, the percentage of change of thought that the author wants to convey, and the percentage of letter/sound similarity were calculated (see Karasu, 2011).

Reading comprehension questions were evaluated over 100 points. Each of the 10 questions asked for each grade level was evaluated over 10 points.

\section{Results and Discussion}

As a result, in terms of syntax and meaning acceptability, there are lower percentage points among students who see less. The same was observed for percentage of error changing meaning, letter-sound similarity and reading comprehension scores. Additionally, the point size and grade level have an effect on the percentages of using clue system of the language of students with low vision.

Reading errors in both groups of students affected reading comprehension. Errors that change meaning are errors that distort the meaning the author wants to convey. The less understandable of the message the author wants to convey may also affect the reader's understanding of what he / she has read. Considering that the first step of understanding is 
decoding; problems that may occur at this stage may lead to low letter/sound similarity. Low letter-to-sound similarity prevents the word from being pronounced correctly, so it can be a barrier to understanding what it reads. When the results were examined students with low vision who have low letter/sound similarity tend to have lowe reading comprehension points

As a result, examining the reading errors of students with low vision through error analysis provides in-depth information about reading errors. The use of miscue analysis with low vision students in the future is important in terms of revealing the current situation of students with low vision and designing appropriate interventions. 